\title{
A Survey of Web Resources for Basic Cancer Genetics Research
}

\author{
Carol J. Bult, ${ }^{1,3}$ Debra M. Krupke, ${ }^{1}$ Barbara J. Tennent, ${ }^{2}$ and Janan T. Eppig ${ }^{1}$ \\ ${ }^{1}$ Mouse Genome Informatics Group, The Jackson Laboratory, Bar Harbor, Maine 04609 USA; ${ }^{2}$ The Jackson Laboratory, \\ Bar Harbor, Maine 04609 USA
}

The purpose of this paper is to summarize information resources and databases available on the World Wide Web that are pertinent to cancer genetics research. We focus primarily on Web resources for basic research as opposed to patient care, clinical trial information, genetic testing, gene therapy, and general cancer health issues. Included in our survey are Web sites that are primarily descriptive, those that are searchable by key words, and those that are linking pages to other cancer research sites. A summary table for the cancer research Web sites described in this paper is provided (Table 1). A summary list of general cancer research Web sites is also provided in Appendix I.

To focus the scope of this survey further, we concentrated on five key areas for basic cancer genetics research: (1) animal models; (2) cancer genetics and genomics; (3) pathology; (4) reagents, services and laboratory protocols; and (5) cancer biology. In Appendix I, we provide a list of some cancer research-related sites that did not readily match any of the five focus areas but that will be of general interest to the community. As we searched for relevant Web sites, we tried to use them to answer the following kinds of research questions:

1. Is there an animal model for the type of cancer I am studying? If so, where can I obtain it? What organism phenotypes are associated with a specific gene-targeted mutation?

2. What is the spectrum of mutations in a gene or genes associated with a particular type of tumor?

What genetic states and changes are associated with tumors and tumor phenotypes?

What are the states of all the known genes in a given pathway for a given cancer?

Is there a comparable mutation in my animal model and humans for the type of cancer my lab is studying?

3. Is there any comparative histopathology between humans and my animal model for the type of tumor my lab is studying? Between normal and cancerous tissues?

4. Where can I obtain tissues, clones, cDNA libraries, and other biological reagents for use in cancer research?

5. Are there any general research-related Web resources available for the type of cancer my lab is studying?

\footnotetext{
${ }^{3}$ Corresponding author.
}

E-MAIL cjb@informatics.jax.org; FAX (207) 288-6131.
Because of the dynamic nature of addresses for information available on the World Wide Web, Table 1 is also available electronically at http://tumor.informatics.jax.org/cancer_links.html. The electronic version will be maintained and updated so that the links to the sites described in this manuscript remain operational. Although we have tried to be comprehensive in our survey, there are undoubtedly some Web resources we did not encounter. Additional cancer research Web sites will be added to the electronic version of the summary table periodically. Readers are encouraged to notify the authors of relevant Web sites for inclusion in this online cancer research information repository.

Animal Models for Cancer Research

Mice and rats serve as the major model systems for cancer research. Animals with different genetic backgrounds vary in their degrees and patterns of susceptibility to different types of tumors and cancer. Researchers can obtain experimental animals from a number of commercial, academic, and nonprofit sources. Increasingly, animals with transgenic, knockout, and/or other targeted mutations are being used to study the effects of specific genes in tumorogenesis. Services for the production of transgenic and knockout animals are available when existing genetically engineered animals are not suitable for a particular research question. The resources described below include suppliers of mice, rats, and other laboratory animals for use in cancer research, transgenic and targeted mutation animal production services, and resources that provide phenotypic/genotypic descriptions of experimental animals. Many of the resources that distribute animals, cells, vectors, and other bioreagents require researchers to sign a material transfer agreement.

\section{Animal Models: Distributors and Animal Production Services}

B\&\&K Universal, Ltd. (UK)

In addition to the 37 strains of mice and rats listed on their Web site, B\&K Universal distributes other laboratory animals including gerbils, hamsters, guinea pigs, beagles, and primates. Information on animal models is not provided online but can be requested from the company. 
Bult et al.

Table 1. A Summary of Web Resources Relevant to Basic Cancer Genetics Research

\begin{tabular}{|c|c|c|c|c|c|c|c|c|c|}
\hline $\begin{array}{l}\text { Resource } \\
\text { Name }\end{array}$ & URL & $\begin{array}{l}\text { Type of } \\
\text { Resource }\end{array}$ & $\begin{array}{l}\text { Organization, } \\
\text { Commercial, } \\
\text { Academic }\end{array}$ & $\begin{array}{l}\text { Subscription } \\
\text { or } \\
\text { Registration } \\
\text { Required for } \\
\text { Access? } \\
\end{array}$ & $\begin{array}{l}\text { Animal } \\
\text { Models }\end{array}$ & $\begin{array}{l}\text { Cancer } \\
\text { Genetics } \\
\text { and } \\
\text { Genomics }\end{array}$ & Pathology & \begin{tabular}{|l|} 
Reagents, \\
Services, \\
Lab \\
Protocols
\end{tabular} & $\begin{array}{l}\text { Cancer } \\
\text { Biology }\end{array}$ \\
\hline \multicolumn{10}{|c|}{ Animal Models: Distributors and Animal Production Services } \\
\hline $\begin{array}{l}\text { B \& K Universal, } \\
\text { LTD. }\end{array}$ & http://www.bku.com/ & Browsable & Com & No & $\bar{\bullet}$ & & & $\bullet$ & \\
\hline Charles River, Inc. & $\begin{array}{l}\text { http://www.criver.com/1998rm/index } \\
\text { html }\end{array}$ & Browsable & Com & No & - & & & - & \\
\hline \begin{tabular}{|l|} 
Chrysalis DNX \\
Transgenic Sciences, \\
Inc. \\
\end{tabular} & $\begin{array}{l}\text { http://www.chrysalisintl.com/transge } \\
\text { nic/ }\end{array}$ & Browsable & Com & No & $\bullet$ & & & - & \\
\hline \begin{tabular}{|l} 
ENU-Mouse \\
Mutagenesis \\
Programme (MRC) \\
\end{tabular} & $\begin{array}{l}\text { http://www.mgu.har.mrc.ac.uk/ } \\
\text { mutabase/ }\end{array}$ & Browsable & Org & No & $\bullet$ & & & - & \\
\hline $\begin{array}{l}\text { The ENU-Mouse } \\
\text { Mutagenesis Screen } \\
\text { Project }\end{array}$ & $\begin{array}{l}\text { http://www.gsf.de/isg/groups/enu- } \\
\text { mouse.html }\end{array}$ & Browsable & Org & No & - & & & - & \\
\hline $\begin{array}{l}\text { Genome Systems, } \\
\text { Inc. }\end{array}$ & http://www.genomesystems.com/ & Browsable & Com & No & - & & & - & \\
\hline $\begin{array}{l}\text { Harlan Sprague } \\
\text { Dawley, Inc. } \\
\end{array}$ & http://www.harlan.com/ & Browsable & Com & No & $\mathbf{0}$ & & & $\bullet$ & \\
\hline $\begin{array}{l}\text { Harwell Mouse Stock } \\
\text { List }\end{array}$ & $\begin{array}{l}\text { http://www.mgu.har.mrc.ac.uk/ } \\
\text { stocklist/stocklist.html }\end{array}$ & Browsable & Org & No & $\bullet$ & & & & \\
\hline $\begin{array}{l}\text { International Mouse } \\
\text { Strains Resource } \\
\text { (IMSR) }\end{array}$ & http://www.jax.org/pub-cgi/imsrlist & $\begin{array}{l}\text { Browsable } \\
\text { Queryable }\end{array}$ & Org & No & $\bullet$ & & & & \\
\hline JAX Mice & http://jaxmice.jax.org/ & \begin{tabular}{|l|} 
Browsable \\
Queryable \\
Linking \\
\end{tabular} & Org & No & $\bullet$ & & & & \\
\hline $\begin{array}{l}\text { Lexicon Genetics, } \\
\text { Inc. }\end{array}$ & http://www.lexgen.com/ & \begin{tabular}{|l} 
Browsable \\
Queryable
\end{tabular} & Com & Register $^{\mathrm{a}}$ & - & & & $\bullet$ & \\
\hline $\begin{array}{l}\text { National Institute of } \\
\text { Genetics (Japan) }\end{array}$ & $\begin{array}{l}\text { http://www.shigen.nig.ac.jp/ } \\
\text { NIG_mouse/mouse.default.html }\end{array}$ & Browsable & Aca & No & $\bullet$ & & & & \\
\hline Taconic, Inc. & http://www.taconic.com/ & Browsable & Com & No & - & & & - & \\
\hline \begin{tabular}{|l|} 
University of \\
Michigan Transgenic \\
Animal Model Core \\
\end{tabular} & http://www.med.umich.edu/tamc/ & $\begin{array}{l}\text { Browsable } \\
\text { Linking }\end{array}$ & Aca & No & - & & & - & \\
\hline \multicolumn{10}{|c|}{ Animal Models: Phenotypes for Genetically Defined and Genetically Engineered Animals } \\
\hline $\begin{array}{l}\text { Database of Gene } \\
\text { Knockouts }\end{array}$ & $\begin{array}{l}\text { http://www.bioscience.org//knockout/ } \\
\text { knochome.htm }\end{array}$ & \begin{tabular}{|l} 
Browsable \\
Linking
\end{tabular} & Org & No & $\bullet$ & & & & \\
\hline $\begin{array}{l}\text { Induced Mutant } \\
\text { Resource (IMR) }\end{array}$ & $\begin{array}{l}\text { http://www.jax.org/resources/ } \\
\text { documents/imr/ }\end{array}$ & \begin{tabular}{|l|} 
Browsable \\
Queryable \\
Linking
\end{tabular} & Org & No & - & & & & \\
\hline $\begin{array}{l}\text { Mouse Knockout \& } \\
\text { Mutation Database }\end{array}$ & http://biomednet.com/db/mkmd/ & \begin{tabular}{|l|}
$\begin{array}{l}\text { Browsable } \\
\text { Queryable } \\
\text { Linking }\end{array}$ \\
\end{tabular} & Com & Subscribe & $\bullet$ & & & & \\
\hline $\begin{array}{l}\text { Transgenic Mice in } \\
\text { Cancer Research }\end{array}$ & $\begin{array}{l}\text { http://www-mp.ucdavis.edu/ } \\
\text { tgmice/firststop.html }\end{array}$ & \begin{tabular}{|l|} 
Browsable \\
Linking
\end{tabular} & Aca & No & • & & - & - & \\
\hline $\begin{array}{l}\text { Transgenic and } \\
\text { Targeted Mutation } \\
\text { Database (TBASE) }\end{array}$ & http://tbase.jax.org/ & \begin{tabular}{|l|} 
Browsable \\
Queryable \\
Linking \\
\end{tabular} & Org & No & - & & & & \\
\hline Transgenic List & $\begin{array}{l}\text { http://www.med.ic.ac.uk/db/dbbm/tgl } \\
\text { ist.htm }\end{array}$ & \begin{tabular}{|l|} 
Email \\
listserver \\
\end{tabular} & Åca & Subscribe & • & & & - & \\
\hline \multicolumn{10}{|c|}{ Cancer Genetics and Genomics } \\
\hline $\begin{array}{l}\text { Androgen Receptor } \\
\text { Mutations Database }\end{array}$ & http://www.mcgill.ca/androgendb/ & \begin{tabular}{|l|} 
Browsable \\
Queryable \\
Linking \\
\end{tabular} & Aca & No & & \begin{tabular}{|c|}
\multicolumn{1}{|c|}{} \\
$\begin{array}{l}\text { Gene- } \\
\text { specific }\end{array}$ \\
\end{tabular} & & & \\
\hline $\begin{array}{l}\text { Ataxia-Telangiectasia } \\
\text { Mutation Database }\end{array}$ & http://www.vmmc.org/vmrc/atm.htm & $\begin{array}{l}\text { Browsable } \\
\text { Linking }\end{array}$ & Org & No & & \begin{tabular}{|c|}
\multicolumn{1}{|c|}{} \\
Gene- \\
specific
\end{tabular} & & & \\
\hline $\begin{array}{l}\text { ATM Mutations } \\
\text { Database }\end{array}$ & $\begin{array}{l}\text { http://www.med.jhu.edu/ataxia/ } \\
\text { mutate.htm }\end{array}$ & \begin{tabular}{|l|} 
Under \\
Construc- \\
tion \\
\end{tabular} & Aca & $?$ & & $\underset{\substack{\text { Gene- } \\
\text { specific }}}{\boldsymbol{-}}$ & & & \\
\hline
\end{tabular}


Table 1. (Continued)

\begin{tabular}{|c|c|c|c|c|c|c|c|c|c|}
\hline $\begin{array}{l}\text { Resource } \\
\text { Name }\end{array}$ & URL & \begin{tabular}{|l|} 
Type of \\
Resource
\end{tabular} & $\begin{array}{l}\text { Organization, } \\
\text { Commercial, } \\
\text { Academic }\end{array}$ & $\begin{array}{l}\text { Subscription } \\
\text { or } \\
\text { Registration } \\
\text { Required for } \\
\text { Access? }\end{array}$ & \begin{tabular}{|l|} 
Animal \\
Models
\end{tabular} & \begin{tabular}{|l|} 
Cancer \\
Genetics \\
and \\
Genomics
\end{tabular} & Pathology & $\begin{array}{l}\text { Reagents, } \\
\text { Services, } \\
\text { Lab } \\
\text { Protocols }\end{array}$ & \begin{tabular}{|l|} 
Cancer \\
Biology
\end{tabular} \\
\hline $\begin{array}{l}\text { Breast Cancer } \\
\text { Information Core } \\
\text { (BIC) }\end{array}$ & $\begin{array}{l}\text { http://www.nhgri.nih.gov/Intramural } \\
\text { _research/Lab_transfer/Bic/ }\end{array}$ & $\begin{array}{l}\text { Browsable } \\
\text { Linking }\end{array}$ & Org & Register & & $\begin{array}{l}\text { Disease- } \\
\text { specific }\end{array}$ & & & \\
\hline $\begin{array}{l}\text { Breast Cancer Gene } \\
\text { Database }\end{array}$ & $\begin{array}{l}\text { http://condor.bcm.tmc.edu/ermb/ } \\
\text { bcgd/bcgd.html }\end{array}$ & $\begin{array}{l}\text { Browsable } \\
\text { Queryable }\end{array}$ & Aca & No & & \begin{tabular}{|l|} 
\\
\\
Disease- \\
specific
\end{tabular} & & & \\
\hline$B R C A I$ & $\begin{array}{l}\text { http://bioinfo.weizmann.ac.il/ } \\
\text { hotmolecbase/entries/brcal.htm }\end{array}$ & $\begin{array}{l}\text { Browsable } \\
\text { Linking }\end{array}$ & Org & No & & $\begin{array}{l}\text { Gene- } \\
\text { specific }\end{array}$ & & & \\
\hline $\begin{array}{l}\text { Cancer Chromosome } \\
\text { Aberration Project } \\
\text { (CCAP) }\end{array}$ & http://www.ncbi.nlm.nih.gov/CCAP/ & $\begin{array}{l}\text { Browsable } \\
\text { Queryable } \\
\text { Linking } \\
\end{array}$ & Org & No & & Human & & & \\
\hline $\begin{array}{l}\text { Cancer Gene } \\
\text { Anatomy Project } \\
\text { (CGAP) }\end{array}$ & $\begin{array}{l}\text { http://www.ncbi.nlm.nih.gov/ } \\
\text { ncicgap/ }\end{array}$ & $\begin{array}{l}\text { Browsable } \\
\text { Queryable } \\
\text { Linking }\end{array}$ & Org & No & & $\begin{array}{c}- \\
\text { Human } \\
\end{array}$ & & & \\
\hline $\begin{array}{l}\text { Chromosomal } \\
\text { Abnormalities in } \\
\text { Cancer }\end{array}$ & $\begin{array}{l}\text { http://www.waisman.wisc.edu/ } \\
\text { cytogenetics/Bmproject/ } \\
\text { CancerCyto.htmlx }\end{array}$ & Browsable & Aca & No & & $\underset{\text { Human }}{\bigcirc}$ & & & \\
\hline $\begin{array}{l}\text { Genes and Disease: } \\
\text { Cancer subsection }\end{array}$ & $\begin{array}{l}\text { http://www.ncbi.nlm.nih.gov/disease/ } \\
\text { Cancer.html }\end{array}$ & Browsable & Org & No & & 0 & & & \\
\hline Gene Cards & $\begin{array}{l}\text { http://bioinformatics.weizmann.ac.il/ } \\
\text { cards/ }\end{array}$ & \begin{tabular}{|l|} 
Browsable \\
Queryable \\
Linking \\
\end{tabular} & Org & No & & \begin{tabular}{|l}
\multicolumn{1}{c}{0} \\
Human \\
Med. Gen.
\end{tabular} & & & \\
\hline HmutDB & $\begin{array}{l}\text { http://croma.ebi.ac.uk/mutations/ } \\
\text { central/ }\end{array}$ & Browsable & Org & No & & \begin{tabular}{|l}
\multicolumn{1}{c}{} \\
\multicolumn{1}{c}{ Human } \\
Med. Gen.
\end{tabular} & & & \\
\hline HotMolecBase & $\begin{array}{l}\text { http://bioinformatics.weizmann.ac.il/ } \\
\text { hotmolecbase/ }\end{array}$ & \begin{tabular}{|l|} 
Browsable \\
Queryable \\
Linking \\
\end{tabular} & Org & No & & \begin{tabular}{|l|} 
\\
Human \\
Med. Gen.
\end{tabular} & & & \\
\hline $\begin{array}{l}\text { HUGO Mutation } \\
\text { Database Initiative }\end{array}$ & $\begin{array}{l}\text { http://www2.ebi.ac.uk/mutations/ } \\
\text { cotton/ }\end{array}$ & $\begin{array}{l}\text { Browsable } \\
\text { Queryable } \\
\text { Linking } \\
\end{array}$ & Org & No & & \begin{tabular}{|l} 
\\
Human \\
Med. Gen.
\end{tabular} & & & \\
\hline $\begin{array}{l}\text { Human Gene } \\
\text { Mutation Database } \\
\text { (HGMD) }\end{array}$ & $\begin{array}{l}\text { http://www.uwcm.ac.uk/uwcm/mg/h } \\
\text { gmd0.html }\end{array}$ & $\begin{array}{l}\text { Browsable } \\
\text { Queryable } \\
\text { Linking } \\
\end{array}$ & Org & No & & \begin{tabular}{l}
\multicolumn{1}{c}{0} \\
Human \\
Med. Gen.
\end{tabular} & & & \\
\hline $\begin{array}{l}\text { Human Mutation } \\
\text { Databases }\end{array}$ & $\begin{array}{l}\text { http://www.hgmp.mrc.ac.uk/Genome } \\
\text { Web/human-gen-db-mutation.html }\end{array}$ & Linking & Org & No & & \begin{tabular}{|l}
\multicolumn{1}{c}{. } \\
Human \\
Med. Gen.
\end{tabular} & & & \\
\hline $\begin{array}{l}\text { The Mammary } \\
\text { Transgene Database }\end{array}$ & $\begin{array}{l}\text { http://mbcr.bem.tmc.edu:80/BEP/ } \\
\text { ERMB/mtdb.html }\end{array}$ & \begin{tabular}{|l|} 
Browsable \\
Queryable \\
Linking \\
\end{tabular} & Aca & No & & $\begin{array}{c}1 \\
\text { Disease- } \\
\text { specific }\end{array}$ & & & \\
\hline$M D M 2$ Database & $\begin{array}{l}\text { http://www.infosci.coh.org/mdm2asp } \\
\text { /default.asp }\end{array}$ & $\begin{array}{l}\text { Browsable } \\
\text { Linking }\end{array}$ & Org & No & & \begin{tabular}{|c|} 
\\
$\begin{array}{c}\text { Gene- } \\
\text { specific }\end{array}$ \\
\end{tabular} & & & \\
\hline $\begin{array}{l}\text { Mouse Genome } \\
\text { Database (MGD) }\end{array}$ & http://www.informatics.jax.org/ & \begin{tabular}{|l|} 
Browsable \\
Queryable \\
Linking \\
\end{tabular} & Org & No & & $\begin{array}{c}0 \\
\text { Mouse }\end{array}$ & & & \\
\hline $\begin{array}{l}\text { Mouse Tumor } \\
\text { Biology Database } \\
\text { (MTB) }\end{array}$ & http://tumor.informatics.jax.org/ & $\begin{array}{l}\text { Browsable } \\
\text { Queryable } \\
\text { Linking } \\
\end{array}$ & Org & No & 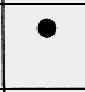 & $\begin{array}{c}0 \\
\text { Mouse }\end{array}$ & 0 & & \\
\hline $\begin{array}{l}\text { NF1 Genetic } \\
\text { Mutation Analysis } \\
\text { Consortium Web Site }\end{array}$ & $\begin{array}{l}\text { http://www.nf.org/nflgene/ } \\
\text { nflgene.home.html }\end{array}$ & Browsable & Org & Register & & $\begin{array}{c}\text { O } \\
\text { Gene- } \\
\text { specific }\end{array}$ & & & \\
\hline $\begin{array}{l}\text { Non-Polyposis } \\
\text { Colorectal Cancer } \\
\text { Mutation Database }\end{array}$ & http://www.nfdht.nl/ & Browsable & Org & No & & $\begin{array}{c}0 \\
\text { Disease- } \\
\text { specific }\end{array}$ & & & \\
\hline $\begin{array}{l}\text { On-line Mendelian } \\
\text { Inheritance in Man } \\
\text { (OMIM) }\end{array}$ & $\begin{array}{l}\text { http://www3.ncbi.nlm.nih.gov:80/ } \\
\text { Omim// }\end{array}$ & \begin{tabular}{|l|} 
Browsable \\
Queryable \\
Linking \\
\end{tabular} & Org & No & & \begin{tabular}{l}
\multicolumn{1}{c}{. } \\
Human \\
Med. Gen.
\end{tabular} & & & \\
\hline p53 Database & $\begin{array}{l}\text { http://perso.curie.fr/Thierry.Soussi/ } \\
\text { p53_database.html }\end{array}$ & $\begin{array}{l}\text { Browsable } \\
\text { Queryable }\end{array}$ & Org & No & & $\begin{array}{l}\text { Gene- } \\
\text { specific }\end{array}$ & & & \\
\hline p53 Database (IARC) & $\begin{array}{l}\text { http://www.iarc.fr/p53/ } \\
\text { Homepage.htm }\end{array}$ & $\begin{array}{l}\text { Browsable } \\
\text { Linking }\end{array}$ & Org & No & & $\begin{array}{l}\text { Gene- } \\
\text { specific }\end{array}$ & & & \\
\hline
\end{tabular}


Bult et al.

Table 1. (Continued)

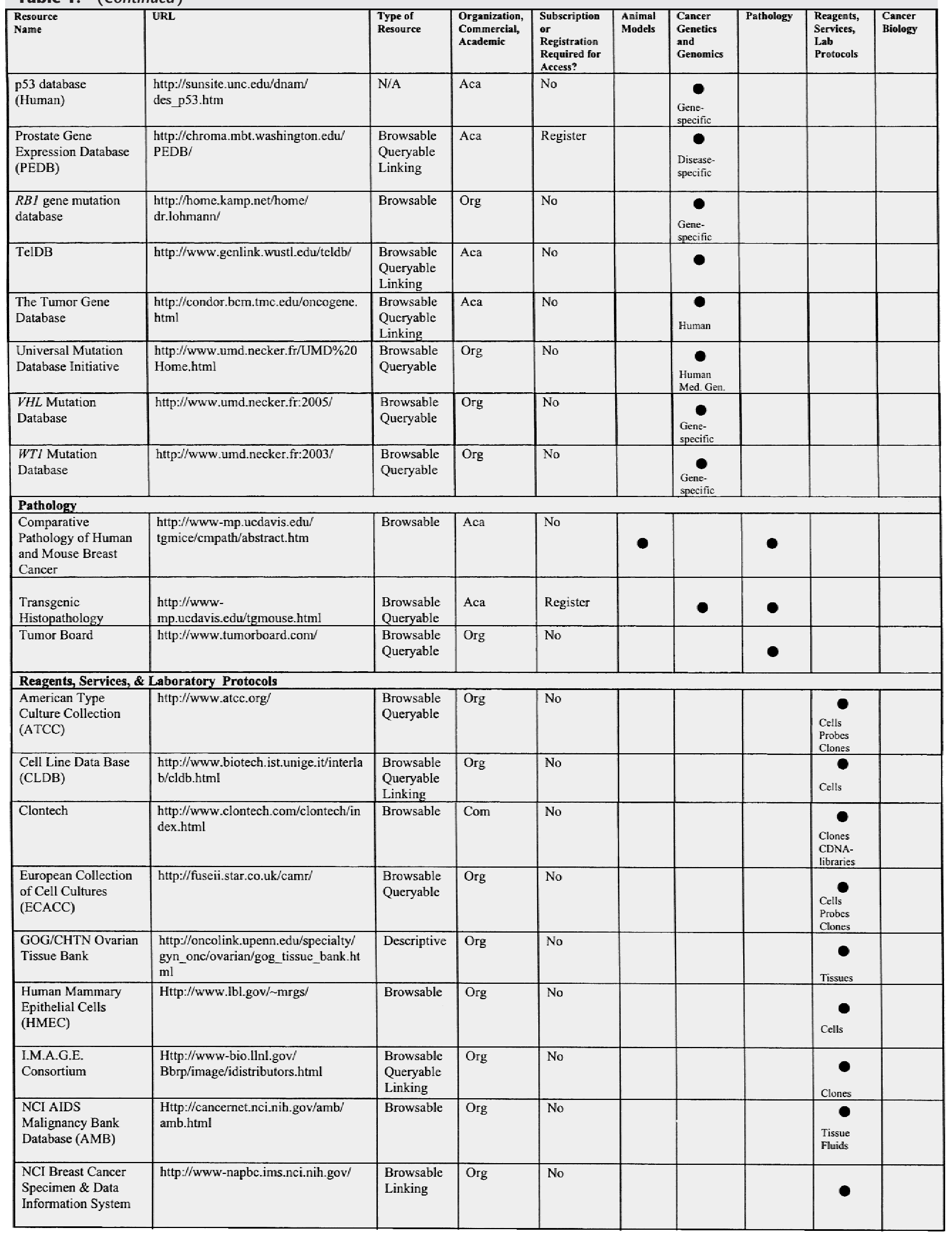


Table 1. (Continued)

\begin{tabular}{|c|c|c|c|c|c|c|c|c|c|}
\hline $\begin{array}{l}\text { Resource } \\
\text { Name }\end{array}$ & URL & $\begin{array}{l}\text { Type of } \\
\text { Resource }\end{array}$ & $\begin{array}{l}\text { Organization, } \\
\text { Commercial, } \\
\text { Academic }\end{array}$ & $\begin{array}{l}\text { Subscription } \\
\text { or } \\
\text { Registration } \\
\text { Required for } \\
\text { Access? } \\
\end{array}$ & $\begin{array}{l}\text { Animal } \\
\text { Models }\end{array}$ & $\begin{array}{l}\text { Cancer } \\
\text { Genetics } \\
\text { and } \\
\text { Genomics }\end{array}$ & Pathology & $\begin{array}{l}\text { Reagents, } \\
\text { Services, } \\
\text { Lab } \\
\text { Protocols }\end{array}$ & $\begin{array}{l}\text { Cancer } \\
\text { Biology }\end{array}$ \\
\hline $\begin{array}{l}\text { NCI Cooperative } \\
\text { Breast Cancer Tissue } \\
\text { Resource Database } \\
\text { (CBCTR) }\end{array}$ & http://www-cbctr.ims.nci.nih.gov/ & $\begin{array}{l}\text { Browsable } \\
\text { Queryable }\end{array}$ & Org & No & & & & Tissues & \\
\hline $\begin{array}{l}\text { NCI Cooperative } \\
\text { Family Registry for } \\
\text { Breast Cancer Studies } \\
\text { (CFRBCS) }\end{array}$ & $\begin{array}{l}\text { http://www- } \\
\text { deeg.ims.nci.nih.gov/cfrbcs/ }\end{array}$ & Browsable & Org & No & & & & $\begin{array}{l}1 \\
\text { Tissues } \\
\text { Fluids } \\
\end{array}$ & \\
\hline $\begin{array}{l}\text { NCI Cooperative } \\
\text { Human Tissue } \\
\text { Network (CHTN) }\end{array}$ & http://www-chtn.ims.nci.nih.gov/ & $\begin{array}{l}\text { Browsable } \\
\text { Linking }\end{array}$ & Org & No & & & & \begin{tabular}{l}
\multicolumn{1}{c}{0} \\
Tissues \\
Fluids \\
Services \\
\end{tabular} & \\
\hline NCI Tissue Expediter & $\begin{array}{l}\text { http://www- } \\
\text { cdp.ims.nci.nih.gov/expediter.html }\end{array}$ & Descriptive & Org & No & & & & $\begin{array}{c}0 \\
\text { Services }\end{array}$ & \\
\hline $\begin{array}{l}\text { The University of } \\
\text { Michigan Human } \\
\text { Breast Cell/Tissue } \\
\text { Bank and Database }\end{array}$ & $\begin{array}{l}\text { http://p53.cancer.med.umich.edu/um } \\
\text { bnkdb.html }\end{array}$ & Browsable & Org & No & & & & $\begin{array}{l}\quad 1 \\
\text { Tissues } \\
\text { Cells }\end{array}$ & \\
\hline \multicolumn{10}{|l|}{ Cancer Biology } \\
\hline $\begin{array}{l}\text { Biology of the } \\
\text { Mammary Gland }\end{array}$ & http://mammary.nih.gov/ & $\begin{array}{l}\text { Browsable } \\
\text { Queryable } \\
\text { Linking } \\
\end{array}$ & Org & Register $^{b}$ & & 0 & 0 & & \\
\hline $\begin{array}{l}\text { Skin Carcinogenesis } \\
\text { and Photodermatoses }\end{array}$ & $\begin{array}{l}\text { http: } / / \text { www.telemedicine.org/Carinog } \\
\text { /carcinog.htm }\end{array}$ & $\begin{array}{l}\text { Browsable } \\
\text { Linking }\end{array}$ & Org & No & & 0 & & & \\
\hline
\end{tabular}

A black dot in a cell indicates that the Web site contains information relevant to that focus area. (In some cases, additional descriptive terms about the Web sites are provided in the cell). Many Web sites contain information relevant to more than one focus area. Web resources are defined as Descriptive, Browsable, Queryable, and/or Linking, depending on the way the information is presented to the user. Descriptive resources provide textual information and an e-mail address for a contact person; Browsable resources are defined as those that provide hyperlinks to different documents within the site; Queryable resources provide key word searching of database or flat files; Linking resources provide hyperlinks to related resources at other sites. Some Web sites require user registration (no fee) or subscription (fee) for access. Web sites are associated with either academic institutions (degree-granting institutions), commercial ventures (companies), or organizations (non-degree-granting research institutions). This information does not imply endorsement by us for any products, services, or information provided by the Web sites or their developers. An electronic version of the information presented in this table can be found at http://tumor.informatics.jax.org/cancer_links.html.

'Registration only required to access Lexicon's Omnibank database.

${ }^{b}$ Registration only required to access the Mammary Gland Gene Anatomy project data.

'(Med. Gen.) Medical Genetics.

Charles River, Inc. (USA)

The Charles River main home page provides links to products and services, health reports, and online literature about quality control information, normative data, and disease agents. In addition to mice and rats, Charles River develops and maintains other kinds of animal models including miniature swine, gerbils, hamsters, guinea pigs, and rabbits. A total of 58 animal models are listed on the Web site, the majority of which are mice and rats. The information regarding stocks of laboratory animals carried by Charles River is browsable but not searchable. Charles River also provides transgenic animal production services.

Chrysalis DNX Transgenic Sciences, Inc. (USA)

Chrysalis offers production services for transgenic mouse and rats, homologous recombination in murine ES cells, and blastocyst injection.
ENU Mouse Mutagenesis Programme Medical Research Council (MRC) (Harwell Mouse Genome Centre, UK)

This Web site provides a browsable list of the mouse mutants and their phenotypes that have been generated by the Medical Research Council (MRC) N-ethyl-Nnitrosourea (ENU) mutagenesis program. Details on obtaining mice are provided on the Web site. A detailed SHIRPA (SmithKline Beecham Pharmaceuticals, Harwell MRC Mouse Genome Centre and Mammalian Genetics Unit, Imperial College School of Medicine at St Mary's, Royal London Hospital, St Bartholomew's and the Royal London School of Medicine Phenotype Assessment) protocol (Rogers et al. 1997) is accessible from the Web site.

\section{ENU-Mouse Mutagenesis Screen Project (GSF, Germany)}

This Web site provides information on the concept of ENU mutagenesis and a hyperlinked list of the mutants currently available from the Forschungszentrum für 
Umwelt und Gesundheit (GSF)-National Research Center for Environment and Health.

Genome Systems, Inc. (USA)

Genome Systems is a commercial source of embryonic stem (ES) cells and mouse embryo fibroblasts (MEFs).

Harlan Sprague Dawley, Inc. (USA)

Harlan's Web site provides browsable links to pricing information for 225 stocks and strains (representing 9 species) of laboratory animals that they distribute. In addition to rats and mice, the company offers hamsters, gerbils, guinea pigs, rabbits, cats, beagles, hounds, and miniature swine. Links to health and genetic monitoring data are provided on the Web site.

Harwell Mouse Stock List (Harwell Mammalian Genetics Unit, UK) Harwell maintains $>200$ strains of mutant mice. The stock lists on the Web site are key word searchable. Ordering information and prices are provided on the Web site.

International Mouse Strains Resource (IMSR) (Harwell Mammalian Genetics Unit, UK; and The Jackson Laboratory, USA)

The IMSR is part of a multicenter collaboration to provide a single Web interface for searching the available mouse strain stocks maintained and distributed by different organizations. Currently the IMSR Web site allows user to search mouse strain stock lists at Harwell Mammalian Genetics Unit and the JAX Mice database at The Jackson Laboratory (Eppig and Strivens 1999).

JAX Mice (The Jackson Laboratory, USA)

The Jackson Laboratory distributes 2300 strains of laboratory mice. The JAX Mice Web site provides a price list and product guide, links to technical support, ordering information, and information on animal health and genetic quality. They also provide a mechanism for searching the JAX Mice database and related databases for mice that can be used as model systems for different diseases.

Lexicon Genetics, Inc. (USA)

Lexicon is a commercial operation specializing in large-scale production of mouse knockouts. The Web site describes the products and services that are offered. Lexicon also maintains a functional genomics database called Omnibank that users can access by registering with the company.

National Institute of Genetics (NIG) Oapan)

NIG distributes 100 strains of laboratory mice. The Web site consists of a hyperlinked list of available stocks listed by type (e.g., congenic, transgenic, etc.). Limited information is available for each strain of mouse listed.

Taconic, Inc. (USA)

The Taconic Web site provides information on the products and services the company offers, a technical library, health reports, lists of publications in which their strains of rats and mice have been used, and a browsable list of the 60 genetically defined mice and rats that they maintain and distribute. The Web site is searchable by key word, but users cannot search the animal models/available stocks specifically. Taconic also offers transgenic animal production services.

University of Michigan Transgenic Animal Model Core (University of Michigan, USA)

This Web site provides information on laboratory protocols, procedural outlines for generating transgenics and targeted mutations, tips on breeding mice, and other useful information. The facility distributes a limited number of plasmids and cell lines to the scientific community. There is a long list of other transgenicrelated Web sites available from the University of Michigan site (http://www.med.umich.edu/tamc/ links.html).

\section{Animal Models: Phenotypes for Genetically Engineered Animals}

Database of Gene Knockouts (Frontiers in Science, USA)

This Web site provides a hyperlinked list of targeted mutations in the mouse arranged alphabetically by gene name, by the affect of the mutation on mouse viability, and by phenotypic effects. References are provided for each entry and are linked to Medline. Gene names are linked to the Transgenic/Targeted Mutation Database (TBASE).

Induced Mutant Resource (IMR) (The Jackson Laboratory, USA)

The IMR database provides information about genetically engineered strains of mice. Included in the searchable database are descriptions of mutant phenotypes, husbandry requirements, and links to outside investigators. Links to the JAX MICE database (strain availability, genetic typing protocols) and the Mouse Genome Database (MGD) (gene mapping and phenotype information) are also provided. A link to the Breast Cancer Resource is available from the IMR home page. The Breast Cancer Resource is a collection of data on transgenic and knockout mice used specifically for breast cancer research.

Mouse Knockout and Mutation Database (MKMD) (Biomednet, USA)

This Web site is a searchable and browsable archive of mouse knockouts and mutations. Users can search by key word and restrict searches by phenotype category and by putative cellular role of the mutated gene. Alternatively, users can browse a list of gene names and select a gene name from the list. Query results are linked to Medline, MGD, SwissProt, and other databases. Members of the community can submit relevant information and data to MKMD electronically. A query history is maintained so users can keep track of past information requests. The service is available by sub- 
scription only. A few example records are available so users can evaluate the service prior to subscribing.

Transgenic Mice in Cancer Research (University of California, Davis, USA) This site is a compilation of information on transgenic mouse research at UC Davis. There is an emphasis on mammary gland cancers. The Web site offers a summary table that links transgenes with tumor phenotypes. The gene names in the summary table are linked to the On-Line Mendelian Inheritance in Man (OMIM) resource at the National Center for Biotechnology Information (NCBI). The Web site also includes links to electronic posters (including the comparative mammary gland biology/pathology of mouse and human), a description of the histopathology services offered at UC Davis School of Medicine, and links to other researchers at the UC Davis Medical Center and School of Medicine who use transgenic animal models in their cancer research.

The Transgenic/Targeted Mutation Database (TBASE) (The Jackson Laboratory, USA)

TBASE is a compilation of the information regarding transgenic and targeted mutation animals from around the world (Jacobson and Anagnostopoulos 1996). The query form allows users to make very specific queries and reports back detailed information about the transgene or knockout construct and phenotype. The site also provides links to other resources including a comprehensive listing of transgenic core facilities and services (http://tbase.jax.org/docs/announce.html\# FACILITIES).

Transgenic List (Imperial College School of Medicine, London, UK)

The Transgenic List is an electronic mail list server to facilitate communication among researchers. The list is open to the public by subscription and is not moderated. Only subscribers to the list are allowed to participate in the forum.

\section{Cancer Genetics and Genomics}

Web resources available for cancer genetics research include those that are gene specific, those that are disease specific, and those that integrate information from many sources. Gene-specific databases generally provide information about the spectrum of mutations observed and the effects of these mutations, if known, on the phenotype of the organism and/or the tumor. Disease-specific sites usually provide information on all the known genes that are associated with a disease phenotype. Web sites are beginning to appear that represent the pattern of gene expression for hundreds or thousands of genes in normal, preneoplastic, and neoplastic cells and tissues. Two genomic sites are described below-the Cancer Gene Anatomy Project (CGAP) and the Prostate Gene Expression Database (PEDB). Integrated databases pull together information about a gene or type of cancer from multiple sources (published and unpublished). Examples of integrated Web resources described below include HotMolecBase, GeneCards, OMIM, MGD, and the Mouse Tumor Biology Database.

Androgen Receptor Mutations Database (McGill University, Canada) This resource represents known associations between mutations in the androgen receptor gene and male prostate cancer. Several image-mapped graphics showing mutation locations and sites for protein interactions along the gene are provided. The European Bioinformatics Institute (EBI) maintains a key wordsearchable version of this database.

Ataxia-Telangiectasia Mutation (ATM) Database (Virginia Mason Research Center, USA)

This site has browsable information about ATM mutations, polymorphisms, and variants.

ATM Mutations Database (Ataxia-Telangiectasia Children's Project, USA)

This resource is still under construction.

Breast Cancer Information Core (National Human Genome Research Institute, USA)

This Breast Cancer Information Core is a consortium for the identification and characterization of breast cancer susceptibility genes. Users must register to use the site. Information such as published laboratory protocols are available to the research community without subscription.

Breast Cancer Gene Database (Baylor College of Medicine, USA)

This Web site is designed along the same lines as the Baylor College of Medicine (BCM) Tumor Genes Database. The database is a compilation of facts about genes involved in breast cancer. The database is searchable by gene name or key word.

BRCAl (Weizmann Institute, Israel)

The URL for BRCA1 points to the entry in the HotMolecBase record for this gene. The database entry is a summary of what is known about human BRCA1 and contains hyperlinks to several online resources for information about the gene.

Cancer Chromosome Aberration Project (CCAP) (NCBI, USA)

CCAP is related to the CGAP resource described below. It is a relatively new initiative and the Web site is still under construction. Currently, the site contains links to the genome-wide map of chromosomal breakpoints in human cancer published by Mitelman et al. (1997). The resource is searchable by key word, and browsable by summary table and by image-mapped ideograms.

Cancer Gene Anatomy Project (CGAP) (NCBI, USA)

CGAP is a resource for the representation of gene expression changes associated with human cancer (Strausberg et al. 1997). It provides links to clone and 
tissue resources for research as well as to descriptions of methodologies related to the project (e.g., cDNA library construction, laser capture microdissection, and expression technologies).

Chromosomal Abnormalities in Cancer (The Waisman Center, University of Wisconsin, USA)

This Web site provides a compilation of human cancers associated with chromosome aberrations. Users can browse the information organized according to the type of cancer or by the type of chromosomal abnormality. Karyotype images for many of the chromosomal abnormalities are available.

Genes and Disease: Cancer Subsection (NCBI, USA)

This Web site comprises a list of some of the most common cancers in humans with links to the genes, mapping information, the published literature, and other Web-based resources. This resource is part of NCBI's summation of genes in humans and their association with various diseases. The Web site represents a useful starting point for accessing a wide variety of data about specific cancers.

GeneCards (Weizmann Institute, Israel)

GeneCards is a key-word searchable database of human genes and gene products. It is primarily a mechanism for loose data integration ("siftware") (Rebhan et al. 1997, 1998). Most of the information in GeneCards is drawn from other, curated databases [Genome Database (GDB), MGD, SwissProt, etc.] and is displayed in an easy-to-read summary. GeneCards currently contains entries for $>7700$ human genes. The entry for each gene displays the official gene, a list of gene name synonyms, homologous genes in other mammals, the name of the gene products, expression patterns, mapped position in the human genome, a list of disorders in which the gene is known to be involved, and medical applications.

HmutDB (European Bioinformatics Institute, UK)

This Web site describes a project by the European Bioinformatics Institute to create an integrated access method and interface for multiple, independent mutation databases (Lehväslaiho et al. 1998). Two browsable integration projects are currently available at the site-the p53 project and mutations reported in the journal Blood, Cells, Molecules, \& Diseases.

HotMolecBase (Weizmann Institute, Israel)

This Web site represents information on biological factors (primarily genes and proteins) that are involved in common human diseases (Rebhan and Prilusky 1997). Users access the information by key-word searching and browsing hyperlinked lists of factors that are in the database. (Currently only 13 factors are included in the resource.) The entries for each factor include a wide breadth of information that is, in turn, hyperlinked to additional resources. Among the standard sets of facts returned for each entry are protein structure, posttranslational modifications, gene expression, cellular functions, metabolism, involvement in diseases, applications, monoclonal antibodies, purification, manipulation, animal models, open questions, contacting researchers, Web resources, and references. This resource is related to the more comprehensive GeneCards project at the Weizmann Institute.

HUGO Mutation Database Initiative (HUGO, UK)

A linking page and information resource for researchers interested in developing mutation databases. The Web site also includes key-word searching on archives of the electronic Mutation Bulletin Board.

Human Gene Mutation Database (HGMD) (Institute of Medical Genetics, Cardiff, Wales)

HGMD is a compilation of published gene mutations that are known to be responsible for inherited human disease. The database does not include somatic mutations or mitochondrial gene mutations. With rare exception, it does not include information on mutations with no obvious effects on phenotype. The database is searchable by key word.

Human Mutation Databases (Human Genome Mapping Project Resource Centre, UK)

A comprehensive linking page for human gene mutation databases, this Web site includes a comprehensive listing of single gene databases (not all are cancerrelated).

\section{The Mammary Transgene Database (BCM, USA)}

The Mammary Transgene Database is a searchable database of experimental results of transgenes expressed in the mammary gland of different species animals (laboratory and agricultural). Users can search by scrolling through selectable lists of the names of regulatory and coding transgenes and expression by species and/or level of expression. Query results include the kind of experiment, details on the transgenes used, and literature references. Some records in this database are linked to The Jackson Laboratory's IMR database.

MDM2 Database (City of Hope, USA)

This browsable resource summarizes what is known about the frequency of gene amplification for the human homolog of transformed mouse 3T3 cell double minute 2 (MDM2) oncogene in humans (Momand et al. 1998). Users can view summary tables and graphics. The database can be down-loaded.

Mouse Genome Database (MGD) (The Jackson Laboratory, USA)

The MGD is a comprehensive repository for published genome mapping, homology, and phenotype information for the laboratory mouse. The database contains information for >9400 mapped genetic loci in the labo- 
ratory mouse. Basic and detailed Web-based forms are used to construct user queries. Query results include map position information, homology data, and phenotype descriptions from the Mouse Locus Catalog.

Mouse Tumor Biology (MTB) Database (The Jackson Laboratory, USA) The MTB Database is designed to support the use of the mouse as a model system of hereditary and induced cancers (Bult et al. 1999). The database is searchable using Web-based forms and provides access to tumor names and classifications, tumor incidence and latency data in different strains of mice, tumor pathology reports and images, information on genetic factors that are associated with tumor biology, and the references associated with these data. MTB query results are linked to other databases including Medline, MGD, and the JAX Mice database.

\section{NF1 Gene Mutation Analysis Consortium (National Neurofibromatosis Foundation, Inc., USA)}

This Web site was established to facilitate communication about mutations, mutation sites, and mutation frequencies in the neurofibromatosis 1 gene (NF1). Access to the site is password protected and is limited to researchers who contribute data. Access to other researchers is considered on a case-by-case basis. The authors of this paper did not request access to the site to review its contents.

\section{Nonpolyposis Colorectal Cancer Mutation Database (International Collaborative Group on Hereditary Nonpolyposis Colorectal Cancer, The Netherlands)}

This Web site contains graphical (image-mapped) representations of the structure of genes known to be involved in hereditary nonpolyposis colorectal cancer. Users can click on the exon of interest to view a table of the known pathogenic mutations and intragenic polymorphisms at that site.

\section{OMIM (NCBI, USA)}

OMIM is an electronic compendium of human genes and genetic disorders. The resource is searchable by genome map position and by key word. Information in the OMIM entries is hyperlinked to numerous external resources including GDB, MGD, HGMD, Medline, and others.

\section{p53 Database (Universal Mutation Database Initiative, France)}

A p53 database (Béroud and Soussi 1998) developed using the Universal Mutation Database methods. The database contains $>9000$ mutations that can be searched using a number of criteria.

p53 Database [International Agency for Research on Cancer (IARC) France] This Web site contains a downloadable listing of all somatic and germ-line mutations and common polymorphisms reported for p53 (Hainaut et al. 1998). The latest version of the database describes $>9000$ muta- tions. The Web site also contains links to published scientific literature on p53 and general information about the molecule and its role in cancer.

p53 Database (Human)

This Web site is a download site for obtaining a human p53 database developed in dBASE and associated software (Cariello et al. 1998). The database includes >5000 mutations including nucleotide base position, amino acid position, and amino acid change, as well as information on cancer type. The database and software are PC compatible only. We did not download this resource for evaluation.

Prostate Expression Database (PEDB) (University of Washington, USA)

PEDB contains $>50,000$ expressed sequence tags (ESTs) from human prostate tissue cDNA libraries. The Web site is designed to provide information on the molecular anatomy of normal, preneoplastic, and neoplastic human prostate. Users must register to access the database. The database supports nucleotide and protein queries against PEDB and links query results to related sites (e.g., CGAP, Unigene, GenBank, etc.). The site also has a repository for PEDB analysis programs.

RB1 Gene Mutation Database (Institut für Humangenetik, Germany) This Web site contains browsable tables of human retinoblastoma 1 gene (RB1) mutations organized by functional categories. Also included are graphical representations of the RB1 gene structure and the distributions of base substitutions, length variation mutations, and missense mutations along the gene.

TeIDB (Washington University, USA)

TelDB is a database of published research literature on telomeres. Information about telomeres in 100 different organisms is available by browsing or via a Webbased query interface. A section of the database is devoted to hot topics in telomere research, including telomeres and cancer. A bulletin board for informal communication about telomere research also is available at the TelDB Web site. No registration is required to participate in the bulletin board discussion.

\section{Tumor Gene Database (BCM, USA)}

The stated goal of Baylor's Tumor Gene Database is to provide a "standard set of facts for all known tumor genes." The resource currently contains information for 300 genes. Users can search the database by gene name or by fact category (>30 categories are provided). Results are returned as a list of facts with hyperlinks to additional information or resources (e.g., OMIM, Medline). The facts are categorized according to their source.

\section{Universal Mutation Database Initiative (Hôpital Necker-Enfants} Malades, France)

This site contains several human gene mutation data- 
bases that are key-word searchable. Users also can review the frequency of mutations by position, view charts of mutations at CpG sites, and generate lists of known insertions and deletions. The gene-specific databases available at this Web site include several genes known to be related to cancer in humans: p53, von Hippel-Lindan tumor-suppressor gene VHL, and Wilms tumor suppressor gene WT1.

VHL Mutation Database (Universal Mutation Database Initiative, France) A database of human VHL (Béroud et al. 1998) mutations and associated analysis software developed by the Universal Mutation Database Initiative group.

WT1 Mutation Database (Universal Mutation Database Initiative, France) A database of human WT1 (Jeanpierre et al. 1998) mutations and associated analysis software developed by the Universal Mutation Database Initiative group.

\section{Pathology}

The majority of Web sites devoted to cancer pathology are clinically oriented. These sites are often designed to teach diagnostic procedures to physicians and clinicians and are not included in this survey. The sites listed below are specifically devoted to the description of pathology and presentation of gross or histological images. Other Web sites listed in Table 1 that provide access to histopathology images include the Mammary Gland Biology Web site, the Skin Carcinogenesis and Photodermatoses Web site, and the MTB Database.

Comparative Pathology of Human and Mouse Breast Cancer (UC Davis, USA) This is an electronic poster comparing human and mouse mammary disease.

Transgenic Histopathology (UC Davis, USA)

This Web site is available to registered users only.

The Tumor Board

This site offers free access to a library of human pathology images. The image library is searchable by key word.

\section{Reagents, Services, and Laboratory Protocols}

The Web sites listed in this focus area of our survey are sources of cell lines, tissues, cDNA libraries, and clones for cancer research. Some of the institutions also provide additional services. Sources of human tissues often distribute them in different forms (e.g., fresh, frozen, paraffin embedded, etc.) but this varies from institution to institution.

American Type Culture Collection (ATCC) (USA)

This Web site is a searchable database and information resource for cell lines, cell cultures, clones, and other bioreagents distributed by the ATCC. Included at ATCC is a searchable and downloadable database of
National Cancer Institute (NCI) Human Tumor Cell Lines compiled by Phelps et al. (1996).

Cell Line Data Base (CLDB) (Italy)

CLDB contains information on $>3900$ cell lines (from humans and other species) that are available through major European cell banks and cell culture collections. The archive is searchable and contains links to OMIM.

Clontech, Inc. (USA)

Clontech is a source for cDNA libraries made from cancerous tissue (humans) and other biological reagents.

European Collection of Cell Cultures (ECACC) (UK)

This Web site is a searchable database for cell lines and cultures distributed by the ECACC.

Gynecologic Oncology Group/Cooperative Human Tissue Network (GOG/CHTN) Ovarian Tissue Bank (Children's Hospital, USA)

This Web site provides contact information for obtaining human ovarian tumors and related tissues for research.

Human Mammary Epithelial Cells (Lawrence Berkeley National Laboratory, USA)

This Web site describes human mammary epithelial cell lines and other bioreagents being made available to the scientific community by Dr. Martha Stampfer.

IMAGE Consortium (Lawrence Livermore National Laboratory, USA)

IMAGE (Integrated Molecular Analysis of Genomes and their Expression) is a consortium of researchers generates sequence, mapping, and expression data for arrayed cDNA libraries from human and mouse (and eventually other species as well). The Web site provides links to United States and European distributors of IMAGE clones as well as to descriptions of the IMAGE consortium. The clones are distributed royalty free.

NCI AIDS Malignancy Bank Database (AMB) (NCI, USA)

AMB provides tissues and biological fluids from individuals with HIV-related malignancies.

$\mathrm{NCI}$ Breast Cancer Specimen and Data Information System (NCI, USA) This Web site provides links to sources of specimens, such as breast tissue (normal and malignant), serum, urine, cells, and DNA, that are needed for breast cancer research.

NCI Cooperative Breast Cancer Tissue Resource Database (CBCTR) (NCI, USA) The CBCTR provides researchers with formalin-fixed, paraffin-embedded primary breast cancer specimens for research purposes. Pathology and clinical data are distributed with the tissue samples. The Web site has a searchable database for identifying the availability of appropriate tissues.

$\mathrm{NCI}$ Cooperative Family Registry for Breast Cancer Studies (CFRBCS) (NCl, USA)

The CFRBCS is a multi-institution consortium that col- 
lects biological specimens from individuals with a family history of breast cancer, breast and ovarian cancer, and Li-Fraumeni syndrome. Family history, clinical, demographic, and other data are available for the specimens.

NCl Cooperative Human Tissue Network (CHTN) (NCI, USA)

This Web site describes the policies, guidelines, costs, and requirements for biomedical researchers wishing to obtain human tissues for biomedical research. An application form is available in PDF format for those wishing to request tissues.

NCI Tissue Expediter ( $\mathrm{NCl}$, USA)

This site describes a service offered by NCI to assist researchers in identifying sources for tissue specimens for their research. An e-mail address for the contact person at NCI is provided.

The University of Michigan Human Breast Cell/Tissue Bank and Database (University of Michigan, USA)

The purpose of this resource is to provide breast cancer researchers with primary breast cells and tissues in a variety of forms that are suitable for a variety of experimental approaches. Breast cells and tissues obtained from this bank come with both demographic and clinical data on the patient sample. Furthermore, users may request cell/tissue samples from patients with specific characteristics, for example, ER-positive or p53positive cells.

\section{Cancer Biology Research Sites}

Although there are many cancer-specific Web sites, most of them are aimed at the patient and clinical audiences. One of the best general cancer information Web sites is OncoLink at the University of Pennsylvania Cancer Center (http://www.oncolink.org). Although they are excellent sources of general cancer information, most cancer-specific Web sites are not included in this survey because they do not meet the criteria of providing information that is directly relevant to basic cancer researchers.

\section{Biology of the Mammary Gland (NIH, USA)}

This comprehensive Web site integrates information about the general biology of the mammary gland and mammary gland cancer with animal models, pathology, genetics, methodologies, and reagents. There also is an electronic message board/discussion forum for posting questions and notices. Most of the information on the Web site is freely browsable; however access to the Mammary Gland Anatomy Project requires registration.

Skin Carcinogenesis and Photodermatoses (The Internet Dermatology Society, USA)

The Web site is part of an electronic textbook on dermatology. The chapter on skin carcinogenesis and photodermatoses contains links to pathology images and entries in OMIM.

\section{Conclusions}

As a result of our Internet survey, we uncovered over seventy Web resources for basic research in cancer genetics. Most of the Web sites fell into three of our five focus areas: animal models, cancer genetics and genomics, and reagents, services, and laboratory protocols. Thus, the following research questions can be addressed directly using Web resources in many cases:

1. Is there an animal model for the type of cancer I am studying?

2. What is the spectrum of mutations in a gene associated with a specific cancer?

3. What organism or tumor phenotypes are associated with a particular targeted mutation?

4. Where can I obtain clones, cDNA libraries, tissues, and other biological reagents for use in my cancer research?

Less common were Web resources that supported exploring the states of all the genes in a particular pathway or of the genes expressed at a particular developmental stage. As genome-level gene expression technologies like those being used in the Cancer Gene Anatomy Project become more accessible, the data to support such questions will become more widely available.

Very few of the online resources we found fit into the pathology or cancer biology focus areas. Thus, answering a question like the following is currently very difficult to address using existing electronic resources with a few exceptions (e.g., the Transgenic Histopathology database, the Mammary Gland Biology Web site, the Skin Carcinogenesis and Photodermatoses Web site, and the MTB database): Is there any comparative histopathology between humans and my animal model for the type of tumor my lab is studying-between normal and cancerous tissues?

How does this survey relate to the bigger picture of cancer genetics information systems? NCI recognizes the need for an effective cancer genetics informatics infrastructure to support connections between heterogeneous data sources and computing environments. NCI's Division of Cancer Epidemiology and Genetics has convened a Cancer Genetics Working Group to outline the requirements for this infrastructure (http:// www-dceg.ims.nci.nih.gov/workgrp/). The development of such a network is, in large part, a moving target because as new technologies emerge new research questions arise that can place unanticipated demands on the infrastructure. In the near future we can expect to find a growing number of "boutique" databases (like many of the ones described in this manuscript) that are cancer specific or are created by experts in a field and designed to address highly focused research questions. In the longer term, however, integra- 
tion of information from various expert domains will be required both for gaining a synthetic view and understanding of cancer genetics and biology and for facilitating the transition from basic research to clinical trials to patient care.

\section{ACKNOWLEDGMENTS}

We gratefully acknowledge the support of the NCI (contract 97CSX022A to J.T.E.) and the U.S. Army Breast Cancer Research Program (DAMD17-94-J-4016 to B.J.T.).

\section{REFERENCES}

Béroud, C. and T. Soussi. 1998. p53 gene mutation: Software and database. Nucleic Acids Res. 26: 200-204.

Béroud, C., D. Joly, C. Gallou, F. Staroz, M.T. Orfanelli, and C. Junien. 1998. Software and database for the analysis of mutations in the VHL gene. Nucleic Acids Res. 26: 256-258.

Bult, C.J., D.M. Krupke, and J.T. Eppig. 1999. Electronic access to mouse tumor biology data: The Mouse Tumor Biology (MTB) Database Project. Nucleic Acids Res. 27: 99-105.

Cariello, N.F., G.R. Douglas, and T. Soussi. 1998. Databases and software for the analysis of mutations in the human p53 gene, the human hprt gene and both the lacI and lacZ genes intransgenic rodents. Nucleic Acids Res. 26: 198-199.

Eppig, J.T. and M. Strivens. 1999. Finding a mouse: The International Mouse Strain Resource (IMSR). Trends Genet. 15: $81-82$.

Hainaut, P., T. Hernandez, A. Robinson, P. Rodriguez-Tome, T. Flores, M. Hollstein , C.C. Harris, and R. Montesano. 1998. IARC Database of p53 gene mutations in human tumors and cell lines: Updated compilation, revised formats and new visualisation tools. Nucleic Acids Res. 26: 205-213.

Jacobson, D. and A.V. Anagnostopoulos. 1996. Internet resources for transgenic or targeted mutation research. Trends Genet. 12: $117-118$.

Jeanpierre, C., C. Béroud, P. Niaudet, and C. Junien. 1998. Software and database for the analysis of mutations in the human WT1 gene. Nucleic Acids Res. 26: 271-274.

Lehväslaiho H., M. Ashburner, and T. Etzold. 1998. Unified access to mutation databases. Trends Genet. 14: 205-206.

Mitelman, F., F. Mertens, and B. Johansson. 1997. A breakpoint map of recurrent chromosomal rearrangements in human neoplasia. Nat. Genet. 15: 417-474.

Momand, J., D. Jung, S. Wilczynski, and J. Niland. 1998.The MDM2 gene amplification database. Nucleic Acids Res. 26: 3453-3459.

Phelps, R.M., B.E. Johnson, D.C. Ihde, A.F. Gazdar, D.P. Carbone, P.R. McClintock, R.I. Linnoila, M.J. Matthews, P.A. Bunn, Jr., D. Carney, J.D. Minna, and J.L. Mulshine. 1996. NCI-Navy Medical Oncology Branch cell line database. J. Cell. Biochem. (Supplement) 24: 32-91.

Rebhan, M. and J. Prilusky. 1997. Rapid access to biomedical knowledge with GeneCards and HotMolecBase: Implications for the electrophoretic analysis of large sets of gene products. Biomed. Biocomput. 18: 2774-2780.

Rebhan, M., V. Chalifa-Caspi, J. Prilusky, and D. Lancet. 1997. GeneCards: Integrating information about genes, proteins and diseases. Trends Genet. 13: 163.

Rebhan, M., V. Chalifa-Caspi, J. Prilusky, and D. Lancet. 1998. GeneCards: A novel functional genomics compendium with automated data mining and query reformulation support. Bioinformatics 14: 656-664.

Rogers, D.C., E.M. Fisher, S.D. Brown, J. Peters, A.J. Hunter, and J.E. Martin. 1997. Behavioral and functional analysis of mouse phenotype: SHIRPA, a proposed protocol for comprehensive phenotype assessment. Mamm. Genome 8: 711-713.

Strausberg, R.L., C.A. Dahl, and R.D. Klausner. 1997. New opportunities for uncovering the molecular basis of cancer. Nat. Genet. (Suppl.) 16: 415-516.

\section{APPENDIX I. GENERAL CANCER RESEARCH WEB SITES}

National Cancer Institute (NCI) http://www.nci.nih.gov

NCI-designated cancer centers http://www.nci.nih.gov/cancercenters

NCI Cancer Information Service http://www.nci.nih.gov/hpage/cis.htm

NCI Surveillance, Epidemiology, and End Results (SEER)

http://www-seer.ims.nci.nih.gov/

International Agency for Research in Cancer (IARC) http://www.iarc.fr/

IARC Cancer Epidemiology Database http://www-dep.iarc.fr

IARC Monographs http://193.51.164.11/default.html

American Association for Cancer Research http://www.aacr.org/

CancerWeb http://www.graylab.ac.uk/cancerweb/research. html

The Carcinogenic Potency Database http://potency/berkeley.edu/cpdb.html

National Toxicology Program http://ntp-server.niehs.nih.gov

Comprehensive journal listings (includes cancer research journals)

http://www.graylab.ac.uk/cancerweb/library/ journals/index.html 


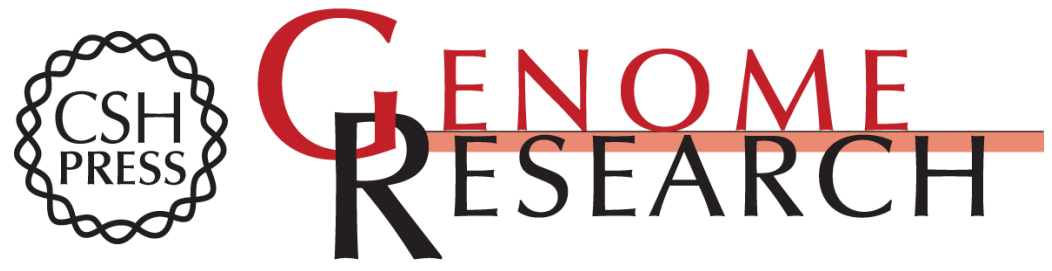

\section{A Survey of Web Resources for Basic Cancer Genetics Research}

Carol J. Bult, Debra M. Krupke, Barbara J. Tennent, et al.

Genome Res. 1999 9: 397-408

Access the most recent version at doi:10.1101/gr.9.5.397

\section{License}

Email Alerting Receive free email alerts when new articles cite this article - sign up in the box at the Service top right corner of the article or click here.

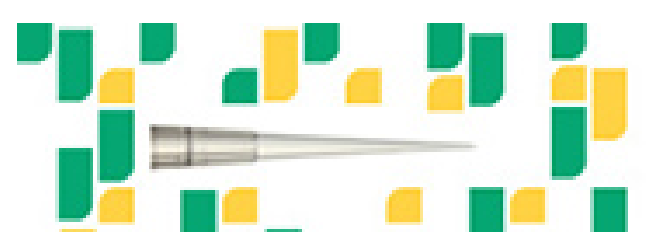

To subscribe to Genome Research go to: https://genome.cshlp.org/subscriptions 